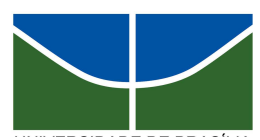

UNIVERSIDADE DE BRASÍLIA

Centro de Excelência em Turismo

Pós-graduação Lato Sensu

Curso de Especialização em Gastronomia e Saúde

\title{
FORMAÇÃO GASTRONÔMICA DO CERRADO - ESTADO DE GOIÁS
}

\author{
Camila Ribeiro Pereira
}

Prof ${ }^{a}$ Orientadora: Verônica Cortez Ginani (Mestre) 


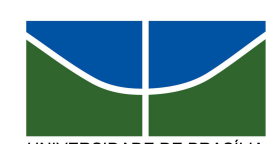

UNIVERSIDADE DE BRASÍLIA

Centro de Excelência em Turismo

Pós-graduação Lato Sensu

Curso de Especialização em Gastronomia e Saúde

\section{FORMAÇÃO GASTRONÔMICA DO CERRADO - ESTADO DE GOIÁS}

Camila Ribeiro Pereira

Prof $^{a}$ Orientadora: Verônica Cortez Ginani (Mestre)

Monografia apresentada ao Centro de Excelência em Turismo - CET, da Universidade de Brasília UnB, como requisito parcial à obtenção do grau de Especialista em Gastronomia e Saúde 
Pereira, Camila Ribeiro.

Formação gastronômica do Cerrado - Estado de Goiás

/ Camila Ribeiro Pereira. - Brasília, 2008.

$40 \mathrm{f}$.

Monografia (especialização) - Universidade de Brasília, Centro de Excelência em Turismo, 2008.

Orientadora: Verônica Ginani.

1. Gastronomia 2.Frutos do cerrado 3. Gastronomia do Cerrado 


\section{UNIVERSIDADE DE BRASÍLIA}

Centro de Excelência em Turismo

Pós-graduação Lato Sensu

Curso de Especialização em Gastronomia e Saúde

\section{Camila Ribeiro Pereira}

Aprovado por:

Professor orientador: Verônica Ginani

Professor: Wilma Araújo

Professor: Fabiana Queiroz

Brasília, 01 de Agosto de 2008. 


\section{DEDICATÓRIA}

Dedico meu trabalho a minha família e amigos que estiveram sempre comigo, e àqueles que se foram, mas que nunca deixaram de acreditar em mim. A minha mãe $e$ protetora a quem devo minha vida e a Universidade de Brasília que ofereceu está oportunidade. 


\section{AGRADECIMENTOS}

Agradeço primeiramente a Deus e a minha mãe por estarem sempre ao meu lado, e a todos os amigos e familiares que me apóiam. Agradeço também a minha orientadora e professores. Obrigada. 


\section{RESUMO}

Por ser uma cultura relativamente nova e em estágio de formação, o Cerrado vem se tornando uma região importante para a gastronomia do Brasil, sendo necessário buscar na história, dados que demonstrem o que figura essa cultura. Buscando compreender as bases da sustentabilidade no interesse da realização do direito de todos ao acesso regular e permanente a alimentos de qualidade, em quantidade suficiente, sem comprometer o acesso a outras necessidades essenciais, tendo como base práticas alimentares promotoras da saúde, que respeitem a diversidade cultural e que sejam ambiental, cultural, econômica. Esse trabalho tem como objetivo analisar o receituário de preparações regionais do Centro-Oeste brasileiro em relação à frequiência de aparição nas citações e presença de frutos do cerrado como ingrediente. Para atingir essa finalidade foram listadas as preparações citadas na literatura especializada; contabilizou-se a freqüência apresentada, além de determinação das influências da formação dessas preparações, incluindo ingredientes trazidos de outras regiões brasileiras e do mundo. Os resultados apresentados aqui mostram a freqüência em que ocorrem receitas do estado que são consideradas típicas e que mais se destacam em livros de receitas brasileiras. $\mathrm{Na}$ pesquisa foram encontrados o arroz com pequi, a guariroba e a pamonha de sal que são sempre relacionados à região pela importância histórica e popular. Analisando os dados das matérias-primas utilizadas nos pratos típicos da região entende-se um pouco mais a cultura da região, e sua importância para gastronomia e alimentação local e brasileira, pois ao estudar os frutos nativos do cerrado damos maior relevância aos frutos. O que gera curiosidade para a utilização dos mesmos e os torna peças necessárias para o desenvolvimento alimentar do local.

Palavras-chave: Gastronomia; Gastronomia do Cerrado; Frutos do cerrado. 


\begin{abstract}
The Cerrado as a relatively new culture and stage of training, it is becoming a very important region for the cuisine of Brazil, being necessary to look in history, data demonstrating what is this culture. Seeking to understand the foundations of sustainability in the interest of achieving the right of all permanent and regular access to food quality, in sufficient quantity, without compromising access to other essential needs, based on feeding practices promoting health, respecting the diversity cultural and which are environmental, cultural, economic. This work aims to analyze the regional preparations receituário of the Brazilian Central West in relation to frequency of appearance in the citations and presence of the cerrado fruit as an ingredient. To this end were listed preparations cited in literature; accounted is often presented as well as determining the influence of training of these preparations, including ingredients brought from other Brazilian regions and the world. The results presented here show the frequency in which they occur revenue of the state that are considered typical and that more prominently in books of Brazilian revenue. In search found the rice with pequi, guariroba and Pamonha of salt that are always connected to the region by historical importance and popular. Analyzing the data of the raw materials used in the dishes typical of the region means a little more the culture of the region, and its importance for food and feed local and Brazil, because by studying the fruit of the native cerrado give greater emphasis to fruit. What generates curiosity to use the same parts and makes necessary for the development of local food.
\end{abstract}

Keywords: Cusine, Cusine of cerrado, fruit of cerrado. 


\section{LISTA DE TABELAS}

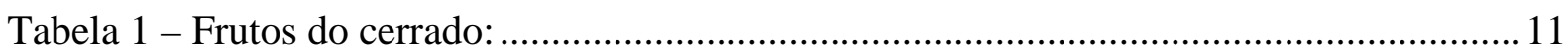

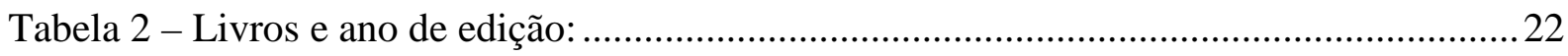

Tabela 3 - Porcentagem de itens encontrados nas fontes de pesquisa: 


\section{SUMÁRIO}

1 INTRODUÇÃO

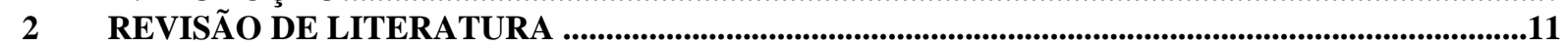

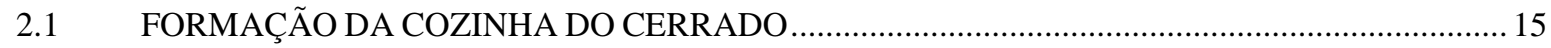

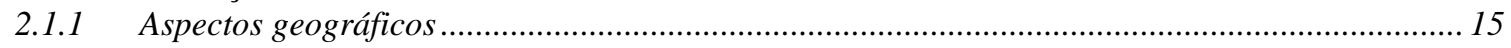

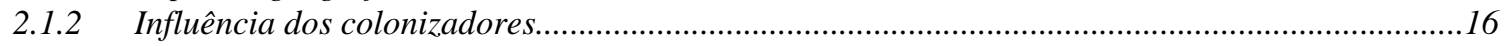

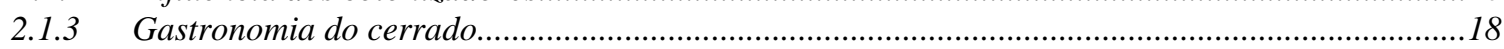

3 MÉTODOLOGIA ........................................................................................................................................... 29

4 RESULTADOS E DISCUSSÃ

5 CONCLUSÃO ....................................................................................................................................................33

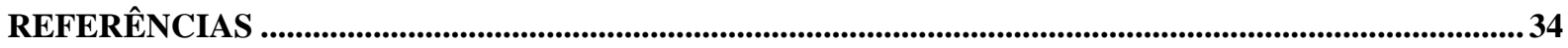

ANEXO A - RECEITA DE ARROZ DE PEQUI..........................................................................................4

ANEXO B: RECEITA DE ARROZ COM GUARIROBA....................................................................................42

ANEXO C: RECEITA DE EMPADÃO GOIANO.............................................................................43

ANEXO D: RECEITA DE GALINHADA......................................................................................................................45

ANEXO E: RECEITA DE PAMONHA DE SAL ..........................................................................................................46

ANEXO F: RECEITA DE PEIXE NA TELHA.................................................................................................47

ANEXO G: RECEITA DE BISCOITO DO CÉU.....................................................................................................48

ANEXO H: RECEITA DEPASTELINHA..................................................................................................................49

ANEXO I: POEMA............................................................................................................................................................................50 


\section{INTRODUÇÂO}

A história alimentar mostra origens, civilidade, comportamentos, culturas. A essência da gastronomia remete mudanças, temporalidade e o passado demonstrado como um processo contínuo da visão sobre as transformações que se mantém e o que acontece eventualmente (ARAÚJO et al., 2005).

A importância da alimentação se evidencia na observação de que outros comportamentos não automáticos não se ligam tão fortemente à sobrevivência humana. A prosperidade leva a esquecer o quanto a fome pode ser impositiva, mas mesmo nesses períodos, os hábitos alimentares continuam sendo veículos de profunda emoção. As atitudes em relação à comida são normalmente aprendidas bem cedo e são, em geral, demonstradas por adultos, o que confere ao comportamento um poder sentimental muito grande (MINTZ, 2001).

Descrever sobre alimentação ou práticas alimentares é hoje uma tarefa extremamente complexa. Existe uma vasta bibliografia sobre ambos, que cresce todos os anos, deixando o pesquisador com a permanente sensação de que é impossível dominar toda a produção da área específica. Somam-se ao fato, as experiências individuais e/ou grupais, vivenciadas no cotidiano de todos, com a convivência de pessoas com hábitos e crenças particulares (BARBOSA, 2007).

Sabe-se que é imprescindível comer todos os dias, durante a vida; o ser humano cresce em lugares, o que aprende sobre comida está inserido em um corpo substantivo de materiais culturais historicamente derivados. $\mathrm{O}$ comportamento relativo à comida revela repentinamente a cultura em que cada um está inserido (MINTZ, 2001).

Quando se estuda a cultura popular no Brasil, uma das primeiras questões é descobrir de onde surgiram esses saberes e sua relação com as múltiplas influências que formaram a cultura brasileira (RODRIGUES, 2001).

Uma das tradições que se destaca é a da região Centro-Oeste. Ali se encontra o cerrado que é considerado um dos biomas mais ricos. A importância da vegetação nativa dessa região é indiscutível, devido a sua multiplicidade de usos, tais como energético, alimentar, medicinal e madeireiro, assim como, para o equilíbrio ecológico (CUNHA, 2003).

A diversidade dos alimentos encontrados no cerrado brasileiro tem despertado o interesse de várias pessoas, inclusive grandes nomes na culinária brasileira e mundial. A 
diversificação das formas de consumo e divulgação desses produtos os torna importantes para a economia da região, onde são cada vez mais produzidos e comercializados (MARIM, 2006).

Essa publicidade, dada aos frutos do cerrado, movimenta a curiosidade sobre suas funcionalidades e formas de preparação (ALMEIDA, 1998). Além de despertar a curiosidade sobre a formação dessa cultura que é tão diversificada.

Mesmo com uma flora tão rica não se pode garantir a segurança alimentar na região, pois faz-se necessário contextualizar a insegurança alimentar e a degradação ambiental, ou seja, os aspectos negativos que envolvem a questão alimentar. De fato, a relação segurança alimentar e meio ambiente deve visualizar as interações entre os recursos naturais e a organização social da comunidade para explorá-los, com o uso do desenvolvimento sustentável, sendo capaz de suprir as necessidades atuais da população, sem comprometer a capacidade de atender as necessidades das futuras gerações e crescendo sem destruir o ambiente e esgotar os recursos naturais (GONÇALVES, 1996).

Esse trabalho tem como objetivo analisar o receituário de preparações regionais do Centro-Oeste brasileiro em relação à freqüência de aparição nas citações e presença de frutos do cerrado como ingrediente. Para atingir essa finalidade foram listadas as preparações citadas na literatura especializada; contabilizou-se a freqüência apresentada, além de determinação das influências da formação dessas preparações, incluindo ingredientes trazidos de outras regiões brasileiras e do mundo. 


\section{REVISÃO DE LITERATURA}

A fome ocorre quando a alimentação diária não remete ao indivíduo energia suficiente para a manutenção do seu organismo e para o desempenho de suas atividades cotidianas, desenvolvendo formas de desnutrição e muitas vezes ocorrendo quando é negado ao indivíduo o seu direito a alimentação (MONTEIRO, 2003).

Segurança alimentar consiste:

[...] na realização do direito de todos ao acesso regular e permanente a alimentos de qualidade, em quantidade suficiente, sem comprometer o acesso a outras necessidades essenciais, tendo como base práticas alimentares promotoras da saúde, que respeitem a diversidade cultural e que sejam ambiental, cultural, econômica e socialmente sustentáveis. (Conselho Nacional de Segurança Alimentar e Nutricional - CONSEA, 2008).

Mesmo com esse direito garantido encontramos altas taxas de fome, ainda que disponibilidade de alimentos venha aumentando nas últimas décadas no Brasil, não parecendo existir problemas na quantidade média de alimentos disponível para o consumo humano no país. Esses dados são controversos a distribuição desses alimentos a população. Ocorrendo uma desigualdade na obtenção desses alimentos (BARRETO, et al., 2005).

Um dos elementos formadores da condição de segurança alimentar, da disponibilidade de alimentos, é a sustentabilidade do sistema alimentar. A sustentabilidade é importante por garantir o acesso ao alimento em quantidade e qualidade adequadas, buscando garantir o futuro aproveitamento e preservação do meio ambiente. Ela esta garantida quando a satisfação das necessidades alimentares no curto prazo não se dá através do sacrifício dos recursos naturais renováveis e não renováveis, tornando possível a preservação das condições que garantam uma disponibilidade de alimentos no longo prazo. Hoje, no Brasil, assim como em grande parte dos países da América Latina e do Caribe, esta sustentabilidade se encontra seriamente comprometida (FERREIRA, 2000).

Para proporcionar o acesso ao alimento é necessário garantir a existência das espécies, onde se faz necessária à preservação da natureza de forma a manter sua diversidade e a variedade contempladas na nutrição humana, sendo possível assim manter a sustentabilidade através da convivência harmoniosa com o meio ambiente (KLIGERMAN, 2007).

Sendo um país tão rico e diversificado é importante a conscientização e preservação da natureza brasileira. Dentre os biomas encontramos o cerrado com uma diversidade grande de frutos importantes na sustentabilidade da região. Com esta enorme biodiversidade criou-se, na 
região do cerrado, uma tradição de usos, em diferentes formas, dos recursos vegetais. Destacam-se pela importância na região, as espécies alimentícias, medicinais, madeireiras, tintoriais, ornamentais, além de outros usos. Das espécies com potencial de utilização agrícola, na região do cerrado, destacam-se as frutíferas. São algumas dezenas de espécies de diferentes famílias que produzem frutos comestíveis, com formas variadas, cores atrativas e sabor característico.

Estes frutos são consumidos em diferentes formas pelas populações locais e constituem, ainda, uma importante fonte de alimentos para animais silvestres (pássaros, roedores, tatus, canídeos, etc.) e mesmo para o gado. Os animais silvestres funcionam como dispersores naturais de sementes, podendo-se admitir que o caráter atrativo e alimentício dos frutos resulta de um processo de co-evolução entre plantas e animais, por um longo período de tempo (CHAVES, 2004).

As fruteiras nativas ocupam lugar de destaque no ecossistema do cerrado e seus frutos já são comercializados em feiras e com grande aceitação popular. Esses frutos apresentam elevados teores de açúcares, proteínas, vitaminas e sais minerais e podem ser consumidos ao natural ou na forma de sucos, licores, sorvetes, geléias etc. Hoje, existem mais de 57 espécies de frutas nativas dos cerrados conhecidas e utilizadas pela população (RODRIGUES, 2001).

Os frutos nativos do Cerrado - base de sustentação da vida silvestre e fonte de alimento para as populações rurais - possuem enorme valor nutritivo. Cem gramas de sementes de Baru fornecem 617 calorias e 26\% de proteína. Em 100 g de polpa de Pequi, encontramos 20 mil mg de vitamina A e 100 g de polpa de Buriti contêm 158mg de cálcio (SILVA et al., 1994 apud SILVA et al., 2001).

O interesse industrial pelas frutas nativas dos cerrados foi intensificado após os anos 40. A mangaba, por exemplo, foi intensivamente explorada durante a Segunda Guerra Mundial, para exploração de látex. O babaçu e a macaúba foram bastante estudados na década de 70, em decorrência da crise de petróleo, e mostraram grandes possibilidades para utilização em motores de combustão, em substituição ao óleo diesel. O pequi já foi industrializado, sendo o seu óleo enlatado e comercializado. A polpa e o óleo da macaúba são utilizados na fabricação de sabão de coco. O palmito da guariroba, de sabor amargo, começou a ser comercializado em conserva recentemente, à semelhança do palmito doce. Os sorvetes de cagaíta, araticum, pequi e mangaba continuam fazendo sucesso nas sorveterias do Distrito Federal e de Belo Horizonte (RODRIGUES, 2001). Em 1975, o IBGE registrou a produção de 33 toneladas de resina de Jatobá e 2.199 toneladas de amêndoas de Macaúba; em 1991, 
registrou 992 toneladas de fibra de Buriti e 2.201 toneladas de Pequi para a extração de óleo (SILVA, et al., 2001).

$\mathrm{Na}$ Tabela 1, que apresenta os diferentes frutos do cerrado, além do período de safra e vegetação de ocorrência, é possível verificar a imensa variedade de frutos comestíveis que compõem o cerrado. São safras intercaladas que permitem a exploração durante todo ano, principalmente no segundo semestre.

Tabela 1: Frutos do cerrado, sazonalidade e vegetação de ocorrência.

\begin{tabular}{|c|c|c|c|}
\hline Nome comum & Nome científico & Frutificação & Vegetação de ocorrência \\
\hline Amora-Preta & Rubus cf brasilliensis & set. a fev. & Mata de Galeria \\
\hline Ananás & Annas ananassoides & out. a mar. & $\begin{array}{l}\text { Cerrado, Cerradão e Mata de } \\
\text { Galeria }\end{array}$ \\
\hline Araçá & Psidium firmum & out. a dez. & Cerrado e Cerradão \\
\hline Araticum & Annona crassiflora & fev. a mar. & Cerrado e Cerradão \\
\hline $\begin{array}{l}\text { Araticum-de-Casca- } \\
\text { Lisa }\end{array}$ & Annona coriacea & dez. a mar. & $\begin{array}{l}\text { Cerrado, Cerradão, Campo } \\
\text { Sujo e Campo Rupestre }\end{array}$ \\
\hline Araticum-Rasteiro & Annona pygmaea & dez. a mar. & Campo Sujo e Campo Limpo \\
\hline $\begin{array}{l}\text { Araticum- } \\
\text { Tomentoso }\end{array}$ & Annona cf. tomentosa & dez. a mar. & Cerrado e Campo Sujo \\
\hline Babaçu & $\begin{array}{l}\text { Orbygnia } c f . \\
\text { phalerata }\end{array}$ & out. a jan. & Mata Seca \\
\hline Bacupari & Salacia campestris & set. a dez. & $\begin{array}{l}\text { Cerrado, Cerradão e Campo } \\
\text { Sujo }\end{array}$ \\
\hline Banha-de-Galinha & Swartzia langsdorfii & ago. a out. & Mata Seca, Mata de Galeria \\
\hline Baru & Dypterix alata & set. a out. & $\begin{array}{l}\text { Mata Seca, Cerradão e } \\
\text { Cerrado }\end{array}$ \\
\hline Buriti & Mauritia vinifera & out. a mar. & Mata de Galeria e Vereda \\
\hline Cagaita & Eugenia dysenterica & out. a dez. & Cerrado e Cerradão \\
\hline $\begin{array}{l}\text { Cajuzinho-do- } \\
\text { Cerrado }\end{array}$ & Spondia cf. lutea $L$. & dez. a fev. & Mata de Galeria \\
\hline $\begin{array}{l}\text { Caju-de-Árvore-do- } \\
\text { Cerrado }\end{array}$ & $\begin{array}{l}\text { Anacardium } \\
\text { othonianum }\end{array}$ & set. a out. & Cerrado e Cerradão \\
\hline Caju-Rasteiro & Anacardium pumilum & set. a out. & Campo Sujo e Campo Limpo \\
\hline $\begin{array}{l}\text { Cajuzinho-do- } \\
\text { Cerrado }\end{array}$ & Anacardium humile & set. a nov. & $\begin{array}{l}\text { Cerrado, Campo Sujo e } \\
\text { Campo Limpo }\end{array}$ \\
\hline Chichá & Sterculia striata & ago. a out. & Cerradão e Mata Seca \\
\hline $\begin{array}{l}\text { Coquinho-do- } \\
\text { Cerrado }\end{array}$ & Syagrus flexuosa & set. a mar. & Cerrado e Cerradão \\
\hline Croadinha & Mouriri elliptica & set. a out. & Cerrado e Cerradão \\
\hline Curriola & Pouteria ramiflora & set. a mar. & Cerrado e Cerradão \\
\hline Fruto-do-Tatu & $\begin{array}{l}\text { Crhysophyllum } \\
\text { soboliferum }\end{array}$ & nov. a jan. & Cerrado e Campo Sujo \\
\hline Gabiroba & $\begin{array}{l}\text { Campomanesia } \\
\text { cambessedeana }\end{array}$ & set. a nov. & $\begin{array}{l}\text { Cerrado, Cerradão e Campo } \\
\text { Sujo }\end{array}$ \\
\hline Gravatá & Bromelia balansae & out. a mar. & Cerrado e Cerradão \\
\hline Guapeva & Pouteria cf. & nov. a fev. & Cerradão, Mata Seca e Mata \\
\hline
\end{tabular}




\begin{tabular}{|c|c|c|c|}
\hline & gardineriana & & de Galeria \\
\hline Guariroba & Syagrus oleraceae & set. a jan. & Mata Seca \\
\hline Ingá-do-Cerrado & Inga laurina Willd.. & nov. a jan. & $\begin{array}{l}\text { Mata de Galeria, Cerradão e } \\
\text { Mata Seca }\end{array}$ \\
\hline Jaracatiá & Jacaratia hiptaphylla & jan. a mar. & Mata Seca \\
\hline Jatobá-do-Cerrado & $\begin{array}{l}\text { Hymenaea } \\
\text { stigonocarpa }\end{array}$ & set. a nov. & Cerrado e Cerradão \\
\hline Jatobá-da-Mata & $\begin{array}{l}\text { Hymenaea } \\
\text { stilbocarpa }\end{array}$ & set. a nov. & $\begin{array}{l}\text { Cerradão, Mata Seca e Mata } \\
\text { de Galeria }\end{array}$ \\
\hline Jenipapo & Genipa ameriacana & set. a dez. & $\begin{array}{l}\text { Mata Seca, Cerradão e Mata } \\
\text { de Galeria }\end{array}$ \\
\hline Jerivá & $\begin{array}{l}\text { Syagrus } \\
\text { romanzoffiana }\end{array}$ & abr. a nov. & Cerradão e Mata de Galeria \\
\hline Lobeira & Solanum lycocarpum & jul. a jan. & $\begin{array}{l}\text { Cerrado, Cerradão e Campo } \\
\text { Sujo }\end{array}$ \\
\hline Macaúba & Acrocomia aculeata & mar. a jun. & Mata Seca e Cerradão \\
\hline Mama-Cadela & $\begin{array}{l}\text { Brosimum } \\
\text { gaudichaudii }\end{array}$ & set. a nov. & Cerrado e Cerradão \\
\hline Mangaba & Hancornia spp. & out. a dez. & Cerrado e Cerradão \\
\hline Maracujá-de-Cobra & Passiflora coccinea & set. a nov. & Mata de Galeria e Cerradão \\
\hline $\begin{array}{l}\text { Maracujá-do- } \\
\text { Cerrado }\end{array}$ & Passiflora cincinnata & out. a mar. & Cerrado e Cerradão \\
\hline Maracujá-Doce & Passiflora alata & fev. a abr. & Mata de Galeria e Mata Seca \\
\hline Maracujá-Nativo & $\begin{array}{l}\text { Passiflora } \\
\text { eichleriana }\end{array}$ & out. a mar. & $\begin{array}{l}\text { Mata de Galeria, Cerradão e } \\
\text { Mata Seca }\end{array}$ \\
\hline Maracujá-Roxo & Passiflora edulis & fev. a ago. & Mata de Galeria \\
\hline $\begin{array}{l}\text { Marmelada-de- } \\
\text { Bezerro }\end{array}$ & Alibertia edulis & set. a nov. & Cerrado e Cerradão \\
\hline $\begin{array}{l}\text { Marmelada-de- } \\
\text { Cachorro }\end{array}$ & Alibertia sessillis & out. a dez. & Cerrado e Cerradão \\
\hline Marmelada-de-Pinto & Alibertia elliptica & out. a dez. & Cerrado e Cerradão \\
\hline $\begin{array}{l}\text { Melancia-do- } \\
\text { Cerrado }\end{array}$ & $\begin{array}{l}\text { Melancium } \\
\text { campestre }\end{array}$ & mai. a jul. & $\begin{array}{l}\text { Cerrado, Campo Sujo e } \\
\text { Campo Limpo }\end{array}$ \\
\hline Murici & $\begin{array}{l}\text { Byrsonima } \\
\text { verbascifolia }\end{array}$ & nov. a mar. & Cerrado e Cerradão \\
\hline Palmito-da-Mata & Euterpe adulis & abr. a out. & Mata de Galeria \\
\hline Pequi & Caryocar brasilliense & out. a mar. & $\begin{array}{l}\text { Cerrado, Cerradão e Mata } \\
\text { Seca }\end{array}$ \\
\hline Pequi-Anão & $\begin{array}{l}\text { Caryocar brasilliense } \\
\text { subsp. Intermedium }\end{array}$ & fev. a abr. & $\begin{array}{l}\text { Cerrado, Campo Limpo, } \\
\text { Campo Sujo e Campo } \\
\text { Rupestre }\end{array}$ \\
\hline Pêra-do-Cerrado & Eugenia klostzchiana & out. a dez. & Cerrado e Cerradão \\
\hline Perinha & Eugenia lutescens & set. a nov. & $\begin{array}{l}\text { Cerrado, Cerradão e Campo } \\
\text { Sujo }\end{array}$ \\
\hline Pimenta-de-Macaco & Xilopia aromatica & set. a jan. & Cerrado e Cerradão \\
\hline Pitanga-Vermelha & Eugenia calycina & set. a dez. & Cerrado e Campo Sujo \\
\hline Pitomba-do-Cerrado & Talisia esculenta & out. a jan. & Mata Seca e Cerradão \\
\hline Puçá & Mouriri pusa & set. a out. & Cerrado e Cerradão \\
\hline Saputá & Salacia elliptica & out. a dez. & Mata de Galeria \\
\hline
\end{tabular}




\begin{tabular}{|l|l|l|l|}
\hline Tucum-do-Cerrado & Bactris spp. & Jan. a mar. & Mata de Galeria \\
\hline $\begin{array}{l}\text { Uva-Nativa-do- } \\
\text { Cerrado }\end{array}$ & Vitis spp. & Jan. a mar. & Mata Seca e Calcária \\
\hline
\end{tabular}

Fonte: (SILVA et. al, 2001)

\subsection{FORMAÇÃO DA COZINHA DO CERRADO}

\subsubsection{ASPECTOS GEOGRÁFICOS}

Goiás é uma das 27 unidades da República Federativa do Brasil. Situa-se a leste da Região Centro-Oeste, no Planalto Central brasileiro. O seu território é de 340.086 km², sendo delimitado pelos estados de Tocantins ao norte, Bahia ao nordeste, Mato Grosso ao oeste, Mato Grosso do Sul a sudoeste, Minas Gerais ao leste e ao sul, além do Distrito Federal. Tendo por capital a cidade de Goiânia (COELHO, 1998).

O estado de Goiás está localizado no coração do Planalto Central brasileiro, entre chapadas, planaltos, depressões e vales. Existe uma grande variação de relevo no território goiano, onde ocorrem terrenos cristalinos sedimentares antigos, áreas de planaltos bastante trabalhadas pela erosão, bem como chapadas, apresentando características físicas de contrastes marcantes e beleza singular. As maiores altitudes localizam-se a leste e ao sul, onde encontram-se a Chapada dos Veadeiros, com elevações acima de 1.200 metros, cujo o ponto mais elevado é o pico Pouso Alto, com 1.784 metros de altitude, a Serra dos Cristais com 1.250 metros e a Serra dos Pireneus com 1.395 metros. As altitudes mais baixas ocorrem especialmente no oeste do estado (RIBEIRO, 1966).

O clima é tropical semi-úmido. Basicamente, há duas estações bem definidas: a chuvosa, que vai de outubro a abril, e a seca, que vai de maio a setembro. A média térmica é de $23^{\circ} \mathrm{C}$, e tende a subir nas regiões oeste e norte e a diminuir nas regiões sudoeste, sul e leste. As temperaturas mais altas são registradas entre setembro e outubro, as máximas podendo as máximas chegarem a até $39^{\circ} \mathrm{C}$. As temperaturas mais baixas, por sua vez, são registradas do entre maio e julho, quando as mínimas, dependendo da região, podem chegar a até $4^{\circ} \mathrm{C}$ (VESENTINI, 1992).

Essas condições geográficas acabam por determina a vegetação existente na região. Com exceção da região do Mato Grosso Goiano, onde domina uma pequena área de floresta tropical existindo árvores de grande porte, aproveitadas pela indústria, como o mogno, jequitibá e peroba, o território goiano apresenta a típica vegetação do Cerrado. Arbustos altos, 
árvores de galhos retorcidos, de folha e casca grossas e raizes profundas formam boa parte da vegetação. Municípios como Goiânia, Anápolis, bem como diversos outros localizados no sul do estado possuem estreitas faixas de floresta Atlântica, as quais, na maioria das vezes, cobrem margens de rios e grandes serras (SEPLAN, 2003).

Ao contrário das áreas de caatinga do Nordeste brasileiro, o subsolo do cerrado apresenta água em abundância, embora o solo seja ácido, com alto teor de alumínio e pouco fértil. Por esse motivo, na estação seca, parte das arvores perdem as folhas para que suas raízes possam buscar a água presente no subsolo. Exemplos de árvores do cerrado são: lobeira, mangabeira, pequizeiro, sucupira, jatobá e de algumas plantas medicinais, como a caroba e a quineira (RIBEIRO, 1966).

A fauna em Goiás é riquíssima, destacando-se animais de variadas espécies, como capivaras e antas, as margens de rios e riachos. Nas matas: onças, tamanduás, macacos e animais típicos do cerrado, como a ema, a seriema, a paca e o tatu. Pássaros de variadas espécies enriquecem a nossa fauna, além de peixes e anfíbios nos rios e lagos espalhados em todo o estado. Para proteger as florestas, a flora e a fauna, foram criados pelo Governo parques e reservas florestais, onde são proibidas a pesca, a derrubada das arvores e a caça. No estado foram criados: Parque Nacional das Emas - em Mineiros no sul do estado. Parque Nacional da Chapada dos Veadeiros - nos municípios de Alto Paraíso e Cavalcante (COELHO, 1998).

Goiás é banhado por três bacias hidrográficas: a Bacia do rio Paraná, a Bacia do Tocantins e a Bacia do São Francisco. Os principais rios são: Paranaíba, Aporé, Araguaia, São Marcos, Corumbá, Claro, Paranã e Maranhão (VESENTINI, 1992).

\subsubsection{INFLUÊNCIA DOS COLONIZADORES}

Os colonizadores portugueses chegaram pela primeira vez à região hoje conhecida como estado de Goiás quase um século após o descobrimento do Brasil (ARAÚJO et al., 2005).

A ocupação do território goiano teve inicio a partir das expedições de aventureiros bandeirantes provenientes de São Paulo entre as quais se destacou a de Bartolomeu Bueno da Silva, o Anhanguera, que seguia em busca de jazidas no final do século XVII. De acordo com a tradição, Bartolomeu Bueno da Silva - diante da recusa dos índios em lhe informar acerca da 
localização das jazidas auríferas de onde retiravam material para as peças de ouro com as quais se enfeitavam - despejou aguardente num prato, ateando-lhe fogo, e ameaçando fazer o mesmo com as águas dos rios. Apavorados, os índios levaram-no imediatamente às jazidas, chamando-no "Anhanguera" (Diabo Velho ou Feiticeiro) (ARTIAGA,1970).

Após a bandeira comandada pelo "Anhangüera", diversas outras expedições partiram em direção a Goiás, em busca de riquezas do subsolo da região. Em 1726, o próprio Bartolomeu Bueno fundou o primeiro vilarejo goiano, o qual foi denominado Arraial da Barra. Subseqüentemente, povoados passaram a multiplicar-se. A exploração do ouro atingiu o seu auge na segunda metade do século XVIII ( POLONIAL, 2005).

A colonização de Goiás deve-se também à migração de pecuaristas que partiram de São Paulo, no século XVI, em busca de melhores terras de gado. Dessa origem ainda hoje deriva vocação do estado para a pecuária (CASCUDO, 2004).

Esses exploradores influenciaram muito na alimentação dessa região pois trouxeram elementos de todo o país como a carne seca do nordeste e o milho dos mineiros. Enquanto garimpeiros buscavam as riquezas como ouro e prata, pecuaristas e exploradores descobriram as vantagens de utilizar a terra para peduária e agricultura (ARAÚJO et al., 2005).

A partir de 1860, a lavoura e a pecuária tornaram-se as atividades principais da região, ao mesmo tempo em que a mineração do ouro entrou em decadência devido ao esgotamento das minas. A navegação a vapor e a abertura de estradas no final do século XIX, possibilitou o escoamento dos produtos cultivados no estado, permitindo o desenvolvimento da região. Em 1889, com a proclamação da república, a província passou a ser o estado de Goiás (COSTA; 1991).

No século XX, a construção da nova capital, Goiânia, foi muito importante para a economia do estado, que deu sinais de um novo surto de desenvolvimento com a criação de Brasília, a nova capital do Brasil, inaugurada em 1960 (ARTIAGA, 1970).

Em 1988, o estado de Goiás foi dividido e sua porção norte passou a constituir o estado do Tocantins. O objetivo principal dessa divisão foi estimular o desenvolvimento da Região Norte, onde estão concentradas as maiores carências sociais e também onde ocorreram com maior freqüência disputas pela posse de terras, provocadas pela concentração fundiária (KOSHIBA, 2003).

O consumo das frutas nativas dos cerrados, há milênios consagrado pelos índios, foi de suma importância para a sobrevivência dos primeiros desbravadores e colonizadores da região. Através da adaptação e do desenvolvimento de técnicas de beneficiamento dessas 
frutas, o homem elaborou verdadeiros tesouros culinários regionais, tais como licores, doces, geléias, mingaus, bolos, sucos, sorvetes e aperitivos. O interesse por essas frutas tem atingido diversos segmentos da sociedade, entre os quais se destacam agricultores, industriais, donasde-casa, comerciantes, instituições de pesquisa e assistência técnica, cooperativas, universidades, órgãos de saúde e de alimentação, entre outros (POLONIAL, 2005).

\subsubsection{GASTRONOMIA DO CERRADO}

Apesar da região se manter quase isolada durante muito tempo, os aspectos geográficos e colonizadores trouxeram muito benefícios para formação cultural e gastronomica do local. Além de se apegarem muito as tradições, onde se utilizavam ingredientes regionais, a população incorporou e manteve as influências de seus vizinhos, os mineiros e dos demais colonizadores (CAVALCANTI, 2007).

Muitas pessoas acreditam que Goiás não tem uma cozinha típica por se tratar de um estado relativamente novo (ARAÚJO et al., 2005), mas ao contrário disso o Estado formou um grande folclore de receitas, história e cultura sobre o pequi e a guariroba, além de outros frutos também regionais como mostra a Tabela 1(CAVALCANTI, 2007).

Esses frutos também são importantes para a formação da gastronomia do cerrado. Como a Amora-Preta que pode ser usada para consumo in natura ou industrializada na forma de sucos naturais e concentrados, fruta em calda, polpa para sorvetes, corantes naturais e produtos geleificados, como geléias e doces cremosos. A amora-preta in natura é altamente nutritiva, contém $85 \%$ de água, $10 \%$ de carboidratos, com elevado conteúdo de minerais, vitaminas B e A e cálcio. Pode ser consumida de outras formas como geléias, suco, sorvete e iogurtes (NACHTIGALL, 2004).

O Ananás ou abacaxi-do-cerrado pode ser consumido ao natural ou industrializado, sob a forma de fatias ou pedaços em calda, abacaxizada, pedaços cristalizados, passa, picles, suco, xarope, geléia, licor, vinho, vinagre, aguardente. Todavia, os principais produtos são as fatias ou pedaços em calda, e o suco. Com o suco do abacaxi podem ser preparados refrescos, sorvetes, cremes, balas e bolos. Como subprodutos da industrialização do abacaxi, obtém-se álcool, ácido cítrico, ácido málico, ácido ascórbico, bromelina (enzima proteolítica que entra na composição de diversos medicamentos) e rações para animais; do restante da planta, são aproveitados industrialmente as fibras e o amido. O suco do abacaxi contém cerca de $12 \%$ de 
açúcar e 1\% de ácidos orgânicos (principalmente ácido cítrico); é considerado boa fonte de vitaminas A e B1, bem como razoável fonte de vitamina C (SPIRONELLO et. al, 2004).

O Araçá ou araçá-do-cerrado é também um fruto encontrado no na região. Os frutos maduros podem ser consumidos ao natural e na forma de sucos, doces, geléias e sorvetes. Servem de alimentos para muitas aves e animais silvestres. A planta pode ser usada também na composição paisagística de praças, parques e na recomposição de vegetação de áreas degradadas do cerrado. $\mathrm{O}$ araçazeiro-do-cerrado é uma planta adaptada às condições dos cerrados remanescentes do Brasil - Central, que abrangem o Distrito Federal e os estados da Bahia, Goiás, Mato Grosso, Mato Grosso do Sul, Minas Gerais, São Paulo e Tocantins (MAEDA et. al, 2006).

Já o araticum, outro fruto muito utilizado na região, quando aberto, oferece uma polpa cremosa de odor e sabor bem fortes e característicos. A polpa pode ser consumida ao natural ou na forma de batidas, bolos, biscoitos e bolachas, picolés, sorvetes, geléias e diversos doces. $\mathrm{O}$ araticum integra a medicina das populações tradicionais da região da Chapada dos Veadeiros, Goiás, que o utilizam como regulador de menstruação, para reumatismo, feridas, úlceras, câncer de pele, fraqueza no sistema digestório, cólicas e contra diarréia (VILAR et. al, 2008).

O Araticum-Tomentoso é um arbusto com 1 a $2 \mathrm{~m}$ de altura, com frutos de cor alaranjada e sua polpa pode ser consumida in natura (SILVA et. al, 2001).

O Araticum-de-Casca-Lisa ou cabeça-de-negro é um arbusto ou árvore pequena da família das anonáceas, que ocorre no Brasil. Possui folhas ovadas, coriáceas, flores amarelas e frutos bacáceos múltiplos, grandes, comestíveis, com sementes tidas como antidiarréicas. Também é conhecido pelos nomes de araticum-do-campo, araticum-dos-lisos e marolinho (NASCIMENTO, 2007).

O Araticum-Rasteiro é um arbusto, com $0,10 \mathrm{~m}$ de altura por $0,20 \mathrm{~m}$ de diâmetro. Possui de 1 a 3 frutos por planta, pesando de 100g a 200g. Polpa amarelada e pode ser consumida em natura (SILVA et. al, 2001).

O Babaçu é uma planta da família das palmáceas Arecaceae, dotada de frutos drupáceos com sementes oleaginosas e comestíveis das quais se extrai um óleo, empregado sobretudo na alimentação, além de ser alvo de pesquisas avançadas para a fabricação de biocombustíveis (LIMA et. al, 2006).

O fruto do Bacupari pode ser encontrado no Brasil da região Amazonica ao Rio Grande do Sul. Hoje em dia é muito difícil encontrar uma árvore dessa fruta, principalmente 
em regiões urbanas. Com frutos comestíveis e muito saborosos é particularmente útil para suprir alimentação à fauna em geral. Característica do interior da mata,de beira de rios e córregos (SANTOS et. al, 1999).

A Banha-de-Galinha ou banana-de-papagaio e uma planta arbórea com 6 a 8m de altura. Com frutos de cor alaranjada e sua polpa pode ser consumida in natura (SILVA et. al, 2001).

O baru tem porte arbóreo, atingindo de 6 a 8 metros de altura por 6 a 8 metros de diâmetro de copa. A planta frutifica em um período muito curto do ano, nos meses de setembro e outubro. Ocorre nas formações de mata seca, cerradão ou cerrado. É exigente em fertilidade, ocorrendo em áreas de solos mais férteis. A polpa do baru é consumida fresca ou em forma de doces, geléias e licores, podendo ser utilizada para sorvetes. A amêndoa é consumida torrada ou em forma de doces e paçoca. O óleo, obtido por meio do processamento das amêndoas, é utilizado na alimentação humana de maneira variada. Sua madeira apresenta alta durabilidade e pode ser utilizada para confecção de mourões. A castanha do baru possui grande riqueza energética, além de vitaminas, sais minerais e gordura vegetal. São ricas em fibras, potássio, proteína, lipídio, fósforo, magnésio, vitamina C e cálcio (BOTEZELLI et. al, 2000).

O buriti é do gênero Mauritia, Mauritiella, Trithrinax e Astrocaryum, da família das palmáceas, de folhas geralmente penatífidas e flabeliformes, coletadas para coberturas de casas rústicas e especialmente para extração de fibras, utilizada em inúmeras obras trançadas; bem como se referir ao fruto e às fibras dessa planta. Da polpa do fruto, denominada saeta, são feitos suco, picolé, sorvete, doce e é utilizado na alimentação de animais (PEREIRA et. al, 2000).

A cagaita é originária do cerrado. É um belo espécime pertencente à família Myrtaceae, encontrada nos estados de Goiás, Minas Gerais, Tocantins, Bahia, Mato Grosso do Sul e São Paulo, nos Cerrados e Cerradões de altitude. Possui uma altura de 4 a $8 \mathrm{~m}$ de altitude dotada de copa densa e alongada. O fruto é uma baga, globosa, grande, glabra, de poupa carnosa e suculenta. É bastante apreciado por animais e também pelo homem. Nos frutos geralmente encontramos de 1 a 3 sementes (CHAVES, 2001).

O Cajuzinho-do-Cerrado tem porte arbóreo, com 10 a $12 \mathrm{~m}$ de altura. Fruto de cor amarelada e a polpa pode ser consumido in natura ou em forma de suco, musse, sorvete e licor. Em excesso pode causar distúrbios digestivos (SILVA et. al, 2001). 
Caju-Rasteiro é uma planta subarbustiva nativa do Brasil, ocorrendo em Minas Gerais e São Paulo. Tem folhas ovaladas. As suas flores são brancas. O pedúnculo dos frutos é carnoso, amarelo, doce e de pequenas dimensões, sendo usado para fazer compotas (ROSSETTI et. al, 2003).

O Caju-de-Árvore-do-Cerrado possui porte arbóreo, com 3 a 4m de altura. Com fruto de polpa branca que é aproveitado em natura ou em forma de suco, licor e doces. A castanha, quando torrada, é consumida com sal ou forma de paçoca doce ou salgada (SILVA et. al, 2001).

Cajuzinho-do-Cerrado é uma planta arbustiva hermafrodita, da família das anacardiáceas. É uma planta nativa do Brasil, ocorrendo no Piauí, em Goiás, Distrito Federal Mato Grosso, Mato Grosso do Sul, Minas Gerais e São Paulo, mas principalmente no planalto central. Pode atingir cerca de $80 \mathrm{~cm}$. Caracteriza-se por vários ramos eretos com base num caule subterrâneo desenvolvido. Possui folhas ovais. As flores podem ser brancas, róseas ou amarelas, com estrias roxas na base. O fruto verdadeiro é uma noz de cor cinzenta e com forma de rim. Tem, contudo, um pseudofruto (tal como o caju), vermelho e claviforme, com polpa branca e suculenta. Tanto o fruto como o pseudofruto são comestíveis, embora o fruto apresente alto teor de acidez (RODRIGUES et. al, 2001).

A Croadinha tem porte arbóreo com 4 a $6 \mathrm{~m}$ de altura. Seu fruto tem polpa alaranjada e pode ser consumida em natura (SILVA et. al, 2001).

O Chichá é uma árvore nativa. Apresenta em grande porte, tronco liso, e perde as folhas durante a floração. Cachos de pequenas flores pintadas de vermelho e alaranjado (CHAVES et. al, 2004).

O Coquinho-do-Cerrado é uma palmeira ornamental, com 3 a $4 \mathrm{~m}$ de altura. Fruto com polpa amarelada, e seu fruto e polpa são consumidos in natura (SILVA et. al, 2001).

A Curriola é uma árvore, geralmente até $8 \mathrm{~m}$ de altura, podendo chegar a mais. $\mathrm{O}$ tronco é reto com casca grossa fissurada. Os frutos são carnosos verde-amarelados quando maduros, em forma de pequena pêra. A polpa doce que envolve a semente é consumida ao natural pela população e por animais silvestres como morcegos. A madeira apodrece facilmente, mas pode ser utilizada em peças que não sofram exposição demasiada ao tempo como ripas, tábuas, divisórias, guarnições usadas internamente em construções, além de brinquedos e caixotes. A raiz e a casca são usadas, na medicina popular, contra vermes e disenteria (MARIMON JUNIOR et. al, 2005). 
O Fruto-do-Tatu é um herbáceo com 10 a $20 \mathrm{~cm}$ de altura. Seus frutos têm polpa de cor branca e podem ser consumidos in natura ou como suco (SILVA et. al, 2001).

O Gravatá é uma espécie herbácea, com 60 a $80 \mathrm{~cm}$ de altura. Possui fruto de polpa branca, consumido in natura ou em forma de doces (SILVA et. al, 2001).

A gabiroba é uma planta nativa do Brasil. É composta por proteínas, carboidratos, niacina, sais minerais e vitaminas do complexo B. Da gabirobeira são utilizados os frutos, as folha e brotos. Possui propriedades medicinais adstringente e antidiarréica. A infusão de suas folhas é relaxante e pode aliviar dores musculares. Os frutos são consumidos in natura e usados em preparos de geléias, sucos, doces, sorvetes, pudins, licores, batidas ou curtidos na cachaça (MELCHIOR et. al, 2006).

A Guapeva é uma planta arbórea com 6 a 8m de altura.Frutos com polpa de cor esbranquiçada e consumidos in natura. Sendo necessário lavar os frutos em água corrente para a retirada do látex ou leite (SILVA et. al, 2001).

O Ingá-do-Cerrado é muito comum nas margens de rios e lagos, é muito procurada pela fauna e pelo homem por suas sementes com arilo branco e adocicado. Existem várias espécies, que se diferenciam pelo tamanho do fruto. Costuma apresentar floração mais de uma vez por ano (MEIRA-NETO et. al, 2002)

O Jacatiá é uma bela árvore frutífera nativa do Brasil, é apenas uma das 21 espécies de plantas frutíferas da família das caricáceas. O nome indigna "jaracatiá" talvez signifique "fruto que queima a língua", devido ao látex extremamente ácido dos frutos. A arvore cresce até 10 metros de altura, em terrenos férteis, das mais variadas formações florestais, sua copa é rala e cônica Os frutos contem substancias papaínicas de ação desobstruentes e antidispépticos, o leite combate as hidropisias e as folhas em cataplasmas curam feridas (ROESLER et.al, 2007).

Jatobá-do-Cerrado Família Leguminosae, mesma do feijão, do baru, da copaíba e do pau-brasil. A família é a primeira entre as mais importantes em termos de número de espécies lenhosas. São mais de 150 espécies agrupadas em três subfamílias. A farinha do jatobá do campo é utilizada em receitas de biscoitos, bolos pães, doces e sorvetes. Alguns benefícios da farinha de jatobá na alimentação foram analisados em trabalho de formulação de biscoitos sem açúcar e fonte de fibras alimentares, para diabéticos ou pessoa sob restrição alimentar (MATUDA et. al, 2005). 
O jatobá-da-mata é uma árvore frondosa cujo tronco pode chegar a ter grandes diãmetros, a ponto de precisar de três pessoas para abraçá-lo e alturas fabulosas, 20, 30 metros ou mais, estando entre as maiores. Seu fruto é muito apreciado pelos primatas e produz uma seiva da qual se faz um remédio para problemas respiratórios, como a asma e bronquite (SILVA et. al, 1998).

O Jenipapo, na medicina caseira, é utilizado como fortificante e estimulante do apetite. Ácida para ser consumida naturalmente, é muito utilizada como matéria-prima alimentícia de doce, licor, xarope, vinho e quinino (sulfato de quinina - usado como antimalárico e antipirético). Sua polpa é suculenta, aromática, comestível e com sementes no centro (ANDRADE et. al, 2000).

O Jerivá é também chamado de baba-de-boi, coco catarro, coqueiro, coqueiro-gerivá, gerivá, coquinho ou jeribá. É da família Palmae, e possui um fruto amarelado. A parte externa, carnosa, é composta de uma mucilagem adocicada muito apreciada por algumas animais, como papagaios e maritacas, ou mesmo pelo humano principalmente a criançada, sendo uma lembrança comum aos interioranos, a quebra destes coquinhos batendo com pedras, para alcançar as suas amêndoas. A árvore fornece também o palmito para alimentação humana. A madeira foi (ainda é) muito usada nas construções rurais como por exemplo o madeiramento de telhados, é utilizado para paisagismo ornamental e também para fazer reflorestamentos em áreas degradadas, preservação permanente, plantios mistos (BERNACCI et. al, 2008).

A Lobeira caracteriza-se por ser uma árvore ou arbusto com até $5 \mathrm{~m}$ de altura. Os frutos dessa espécie são os maiores do gênero, chegando até $13 \mathrm{~cm}$ de diâmetro. Fazem parte da alimentação do lobo-guará e do homem, sendo usados na confecção de doces e geléias. Também são usados, ainda, na medicina popular, em tratamentos contra o diabetes (ELIAS et. al, 2003).

A macaúba, coco-baboso ou coco-de-espinho é uma palmeira nativa brasileira Com altura até 15 metros, a árvore é ornamental. Seus frutos são comestíveis, e de sua amêndoa se extrai um óleo fino semelhante ao da oliveira. Do miolo do tronco se faz uma fécula nutritiva, as folhas são forrageiras e têm fibras têxteis usadas para fazer redes e linhas de pescar. A madeira é usada em construções rurais (OLIVEIRA et. al, 2006).

A Mama-cadela pode ser encontrada na forma de arbusto ou arvoreta, atingindo até $4 \mathrm{~m}$ de altura. Os frutos tem coloração alaranjada, alcançando $3 \mathrm{~cm}$ de diâmetro, comestível ao natural ou na forma de sorvete e doces. Planta muito utilizada pelas populações do Cerrado, 
como espécie medicinal contra gripes e bronquites, como depurativo do sangue e em má circulação. A casca é comercializada em bancas de raizeiros da região (JACOMASSI et. al, 2007).

A Mangaba é o fruto da mangabeira, também chamada de mangaba-ovo. É comestível e utilizado na fabricação de bebida vinosa. A mangabeira é uma árvore que pode atingir os sete metros de altura, pertencendo à família das apocináceas. Seu látex é usado para fazer uma borracha de cor rosada. Sua madeira é de cor avermelhada, com folhas em formato elíptico e flores grandes (SILVA JÚNIOR, 2004).

O Maracujá-de-Cobra é uma trepadeira com frutos de polpa cor creme, que podem ser consumidos in natura ou como doces, sorvetes, musses ou sucos (SILVA et. al, 2001).

Maracujá-do-Cerrado A Passiflora cincinnata conhecida popularmente como maracujá-do-cerrado ou maracujá-do-mato nasce nas bordas das matas do cerrado (FALEIRO et. al, 2005)

O Maracujá-Doce é uma trepadeira, e seu fruto pode possuir polpa branca ou amarelada sendo utilizada para consumo in natura ou emforma de geléias, doces, sucos e sorvetes (SILVA et.al, 2001).

O Maracujá-Roxo cresce em trepadeira herbácea ou lenhosa que pode atingir mais de $10 \mathrm{~m}$ de comprimento, de folhas verdes, brilhantes na face superior, simples, alternadas, ovadas, elípticas, lobadas ou digitadas. As flores hermafroditas e de rara beleza, são brancas e roxas e possuem um perfume intenso. Os frutos são de cor púrpura, com forma de ovo, de casca dura e rugosa, de polpa amarela, sumarenta e com pequenas sementes pretas (MELETTI et. al, 2005).

O Maracujá-Nativo ou maracujá sururuca é uma trepadeira, com frutos de polpa amarelo ou creme, usados in natura, ou em forma de doces ou suco (SILVA et. al, 2001).

A Marmelada-de-Bezerro é uma árvore de até $4 \mathrm{~m}$ de altura e copa com $3 \mathrm{~m}$ de diâmetro. Folhas de coloração verde-intensa, brilhantes. Flores brancas. Com fruto Globoso com casca lisa, negra quando maduro. Polpa comestível de coloração negra que envolve numerosas sementes. Frutifica durante o ano inteiro e mais frequentemente de setembro a novembro (BARREIRO et. al; 2007).

A Marmelada-de-Cachorro ou marmelada-nativa é uma planta arbórea, com 3 a $5 \mathrm{~m}$ de altura. Possui frutos com casca e polpa escura, que são aproveitados in natura ou em geléias (SILVA et. al, 2001). 
A Marmelada-de-Pinto ou Puruí-peva vem do Tupi-guarani e quer dizer "Fruta acre e doce" isso porque lembra o sabor forte da marmelada, com um doce muito agradável e Peva quer dizer chato ou baixo. Arbusto de $60 \mathrm{~cm}$ de altura, que forma pequenas moitas rasteiras, com galhos elípticos, isto é procedendo dum mesmo ponto. Os frutos são consumidos in natura e na forma de geléia (BOLZANI et. al, 2006).

A melância-do-cerrado ou cabacinha é uma espécie rara dos ecossistemas do cerrado do Brasil. Infelizmente a espécie está ameaçada de extinção. A planta é bienal e rasteira e de ramas longas medindo 2 a 5 metros de comprimento. Os ramos são revestidos de pelos ásperos, a folha é em forma de coração, de textura áspera ao tato e quebradiça, a margem da folha tem recortes arredondados ou levemente partida, com 3 nervuras centrais bem visíveis. As flores são pequenas de cor amarelo-creme e nascem no ápice das folhas. Os frutos são bagas com casca grossa, com aproximadamente 90 sementes com películas envoltas numa polpa gelatinosa amarelada de sabor subácido. A polpa é melhor aproveitada na forma de sucos (BATALHA et. al, 2001).

A Uva-do-Cerrado ou uva-nativa é uma planta trepadeira, que atinge até $40 \mathrm{~m}$ de comprimento sobre rochas calcárias. Produz frutos com cascas cor vinho e polpa branca. A polpa é utilizada in natura ou em forma de geléia (SILVA et. al, 2001).

O Murici é fruteira arbustiva. Seus frutos são amarelos, medindo de 1 a $2 \mathrm{~cm}$. Seu sabor exótico confere a esta fruta características únicas. A polpa pode ser utilizada na preparação de sucos, sorvetes, vinhos e licores (REZENDE et. al, 2003).

A árvore da perinha tem porte arbustivo, com 0,80 a $1 \mathrm{~m}$ de altura. Possui fruto de polpa amarelada que é consumida in natura ou em forma de sucos e geléias (SILVA et. al, 2001).

O Palmito-da-Mata fornece o palmito comum; tronco alto, liso, delgado, reto, de coloração acinzentada. A polpa é consumida em forma de sucos e sorvetes, e utilizado em pratos típicos como o frango com palmito (MARTINS-CORDER et. al, 2006).

A Pêra-do-Cerrado é uma árvore de porte arbustivo, medindo 0,80 a $1 \mathrm{~m}$ de altura. Fruto com polpa branca, que é consumida in natura, ou em forma de sucos e geléias (SILVA et. al, 2001).

A Pimenta-de-Macaco é uma árvore até $6 \mathrm{~m}$ de altura com casca escura e copa rala. Folhas com pilosidade em ambas as faces, de coloração verde-intensa. Forma irregular, de coloração esverdeada. Polpa avermelhada contendo sementes escuras, quase negras, envoltas por arilo branco. No dicionário de Pio Corrêa, consta que as sementes da pimenta-de-macaco 
são aromáticas e condimentares, podendo substituir a pimenta-do-reino ou pimenta-da-índia moída. Dessa forma, costumam servir como tempero nas culinárias regionais brasileiras, oferecendo uma explicação possível para seus nomes populares (GAIA et. al, 2004).

O Tucum-do-Cerrado é uma palmeira com 4 a $6 \mathrm{~m}$ de altura. Com frutos de polpa violácea, que podem ser consumidos in natura ou em forma de sucos, sorvetes, geléias, vinhos e vinagre (SILVA et. al, 2001).

A pitanga ou pitanga-vermelha tem seu nome derivado do tupi pi'tãg, que quer dizer vermelho-rubro, em alusão à cor de seu fruto, que de fato pode se apresentar nas cores vermelha, rubra, roxa, e as vezes quase preta, sendo esta conhecida popularmente como pitangueira. O fruto é uma baga globosa, de sabor doce ácido, e o aroma muito intenso e característico. No Brasil e particularmente no Nordeste, a pitanga é consumida ao natural, mas sua principal utilização está no aproveitamento, industrial e doméstico, dos frutos para o preparo de polpas e sucos. Também é utilizado na fabricação de sorvete, picolé, refresco, geléia, licor e vinho (MIELKE et. al, 1995).

O Saputá planta de porte arbóreo, com 6 a $8 \mathrm{~m}$ de altura. Fruto com polpa branca, utilizada in natura (SILVA et. al, 2001).

A pitomba, é a fruta da pitombeira. Seus frutos são comestíveis, saborosos e muito consumidos tanto pelo homem como pela fauna. A pitomba possui em geral um a dois caroços revestidos por uma camada fina e suculenta, adocicada e um pouco ácida. Muito rica em vitamina $C$, não é usada em preparações culinárias; seu consumo é melhor ao natural Quando maduros, a fruta tem a cor laranja e em média cerca de três centímetros (SANTOS et. al, 2008).

O Puçá ou mandapuçá é de porte arbóreo, com 6 a 8m de altura. Possui frutos de polpa alaranjada que pode ser consumida in natura (SILVA et. al, 2001).

O pequi (Caryocar brasiliense; Caryocaraceae) é uma fruta nativa do cerrado brasileiro, muito utilizado na cozinha nordestina, do centro-oeste e norte de Minas Gerais. Dela é extraido um azeite denominado azeite de pequi. Seus frutos são também consumidos cozidos, puros ou juntamente com arroz e frango. Seu caroço é dotado de muitos espinhos, e há necessidade de muito cuidado ao roer o fruto, evitando cravar nele os dentes, o que pode causar sérios ferimentos nas gengivas. $\mathrm{O}$ sabor e o aroma dos frutos são muito marcantes e peculiares. Pode ser conservado tanto em essência quanto em conserva. Também pode ser utilizado na galinhada que é um prato incorporado a cultura, se trata da galinha frita e mergulhada no molho de tomate (LIMA et al., 2007). Uma de suas variações é o pequi-anão 
(Caryocar brasiliense subsp. Intermedium), um pequeno arbusto de no máximo 1,50 m. de altura. A produção de mudas é feita por sementes. (MELO, 2001).

Símbolo da cultura do estado de Goiás, o pequi, árvore da família das cariocáceas pode também ser encontrada em toda a região Centro-Oeste, considerada a capital da fruta, e nos estados de Rondônia ao leste, Minas Gerais ao norte e oeste, Pará ao sudoeste, Tocantins, Maranhão no extremo sul, Piauí no extremo sul, Bahia ao oeste e Ceará ao Sul. Em Goiás podem ser encontradas todas as espécies, cuja frutificação ocorre entre os meses de setembro e fevereiro (SILVA JÚNIOR, 2005).

$\mathrm{O}$ arroz com pequi é extremamente apreciado, sendo sem dúvidas uma iguaria regional. Goiás é, também, um grande produtor de arroz (ARAÚJO et al., 2005) .

Já a guariroba é uma palmeira de estirpe ereto, podendo atingir até $20 \mathrm{~m}$ de altura, copa crispada e deflexa. Folhas grandes de até $3 \mathrm{~m}$ de comprimento. Flores surgem em cachos durante a primavera até o outono. O seu fruto é dado em cachos, de coloração verdeamarelada, com uma amêndoa branca oleaginosa comestível. Frutifica de outubro a fevereiro. O cultivo desta palmeira é por sementes, embora cresça espontaneamente nas matas do Sudeste do Brasil. Prefere regiões de clima quente e solos bem drenados (MELO, 2002.)

Entre seus produtos destaca-se o palmito ou broto terminal. Considerado por muitos como verdura de sabor amargo - o que de fato é, quando comparado aos palmitos doces das espécies da Mata Atlântica, o palmito da guariroba é uma iguaria de largo aproveitamento culinário. Especialmente em algumas regiões de Minas Gerais e de Goiás, como nas boas receitas de empadão goiano, por exemplo e como acompanhamento perfeito para o colorido arroz com pequi. Além de ser utilizado na preparação de arroz com guariroba, outro prato muito apreciado na região (SILVEIRA et al., 2005).

O empadão goiano é um alimento substancial e de tempero bem forte, o recheio desse, juntamente com a guariroba, deve conter pedaços de frango, de preferência coxas, carne de porco, batatas e ovos cozidos inteiros ou apenas partidos ao meio, e tomates maduros. Existindo também variações igualmente saborosas (FERNANDES, 2007).

Juntamente com esses alimentos, encontramos o peixe na telha um prato típico brasileiro, característico da culinária dos estados de Goiás e Espírito Santo. O prato é uma receita bem conhecida, sendo preparada em uma telha de barro qualquer e o peixe pode ser escolhido entre jaraqui, curimbatá (papa-terra), corvina ou piracanjuba. Sempre acompanhado de arroz branco e um molho a base de cebola e tomate picados finamente com vinagre e óleo (CAVALCANTI, 2007). 
Também considerada prato típico mas trazida de Minas Gerais e adaptado para a região a pamonha se tornou um prato típico. Sendo preferida na versão salgada e com a adição de outros ingredientes e formas de cozimento conhecida como "di a moda". Como a pamonha de sal com linguiça, a pamonha assada e a pamonha frita (FERNANDES, 2007).

A confeitaria Goiânia é marcada por frutas exóticas do cerrado como: abacaxi, jabuticaba, pequi, guariroba, jenipapo, entre outras, utilizadas em diversas preparações. Figura de destaque na cultura goiana, a renomada poetisa e doceira Cora Coralina, que passou uma boa parte de sua vida vendendo doces para sustentar a família. Um exemplo típico da influência na culinária é o pastelinho. Seus ingredientes fazem lembrar os famosos Pasteizinhos de Belém, criado no mosteiro de Jerônimos no inicio do século XIX, com a chegada da Cana-de-açúcar. Quando Goiás estava com sua economia estacionada na década de 1930, as quituteiras assavam os doces em latas de goiabada e vendiam para o comércio. E foi aos poucos que os famosos pastelinhos, foram virando mercadorias, mantendo ainda o ar caseiro. Não há registros oficiais sobre o pastelinho, ainda assim sabe-se que a receita é uma tradição passada de geração em geração (ARTIAGA, 1970).

O pastelinho é bastante consumido na cidade de Goiás, feito tanto por quituteiras em suas próprias casas, quanto encomendados por profissionais, todos seguindo os princípios tradicionais. A massa do pastelinho pode ser assimilada com a do Pâtè Sucrée, pois apresenta uma porcentagem de gordura deixando-a mais crocante. Seu diferencial é ser uma massa de preparo rápido, mas delicado (LACERDA, 1997).

Além desse, encontramos muitos outros doces que fazem sucesso na gastronomia do Goiás dentre eles o biscoito do céu que é típico da região norte do estado, sendo um sequilho mais fino. É composto de coco, açúcar, ovos e polvilho, basicamente (CAVALCANTI, 2007).

Muitas outras receitas fazem parte do repertorio culinário goiano, sendo eles produtos que nasceram ou produtos vindos para compor a cultura da região. Por ser uma culinária extremamente saborosa, se tornou e vem se tornando muito importante para a gastronomia de todo o país. 


\section{METODOLOGIA}

Esta é uma pesquisa como método de procedimento histórico. Os instrumentos de investigação que foram utilizados são bases de levantamento bibliográfico teórico.

A população investigada englobou a região Centro-Oeste com foco no estado de Goiás, por ser uma região extremamente banhada por esse bioma.

Analisou-se 23 fontes da literatura sendo elas livros de receitas, que foram escolhidas de acordo com a ligação com as receitas da culinária brasileira, com preferência aos títulos que davam ênfase a culinária da região Centro-Oeste. Estes foram selecionados por serem escritos ou traduzidos em português e os editados nos últimos dez anos.

Tabela 2: Lista de livros de receitas da região Centro-Oeste e ano de edição

\begin{tabular}{|l|l|}
\hline \multicolumn{1}{|c|}{ Fontes } & Ano \\
\hline 100 Receitas de Arroz & 2003 \\
\hline 100 Receitas de Pescados & 2008 \\
\hline 100 Melhores Receitas de Restaurantes & 2006 \\
\hline 400 Receitas Práticas De Dona Mimi & 1998 \\
\hline 500 Anos de Gastronomia em Terra Brasilis & 2000 \\
\hline 1000 Receitas da Culinária Brasileira. & 2005 \\
\hline A pátria nas panelas - história e receitas da cozinha brasileira & 2007 \\
\hline Brasil - Ritmos e receitas & 2006 \\
\hline Brasil Receitas de Criar e Cozinhar & 1998 \\
\hline Cozinha da Roça - Delícias do Brasil Interiorano & 1998 \\
\hline Cozinha goiana & 2000 \\
\hline Histórias e Receitas - Deliciosas lembranças no fazer pedagógico & 2007 \\
\hline O Grande Livro de Receitas & 1998 \\
\hline O Livro da Cozinha Clássica - A história das receitas mais famosas da história & 2003 \\
\hline Peixes - 80 das Melhores Receitas & 2007 \\
\hline Receitas de Anita - Doces e Salgados & 2005 \\
\hline Sabor Rural - 50 Receitas com tempero de Brasil & 2004 \\
\hline Sabores da cozinha brasileira & 2004 \\
\hline Sabores do Brasil - receitas de Embaixada & 2006 \\
\hline
\end{tabular}




\begin{tabular}{|l|l|}
\hline Santas Receitas & 2007 \\
\hline Viagem gastronomica através do Brasil & 2007 \\
\hline Cerrado: aproveitamento alimentar & 1998 \\
\hline Frutas do Cerrado & 2001 \\
\hline
\end{tabular}

Os pratos foram considerados típicos quando citados por no mínimo $70 \%$ dos livros, por utilizar ingredientes regionais e pela sua inserção na cultura local (Tabela 3).

Foram analisados os ingredientes dos pratos selecionados, com ênfase nas frutas do cerrado, para que se fizesse referência ao histórico do ingrediente e para discutir a influência da colonização nos pratos típicos. Os registros históricos da região foram revisados para que se pudesse fazer um levantamento das preparações que fazem parte do crescimento e desenvolvimento da cultura do estado e a utilização das frutas do cerrado utilizadas nestas receitas. 


\section{RESULTADOS E DISCUSSÃO}

Foram analisadas 23 fontes de receitas. Por eles foram selecionados oito pratos considerados típicos, pois tiveram uma repetição acima de $70 \%$ do total de fontes.

Ficando a distribuição como apresentado na Tabela 3.

Tabela 3. Frequencia das receitas da Região Centro-Oeste encontrados na literatura.

\begin{tabular}{|l|c|c|}
\hline Preparação Salgada & Porcentagem das fontes & Número de fontes \\
\hline Arroz de pequi & $95,6 \%$ & 22 \\
\hline Arroz com guariroba & $82,6 \%$ & 19 \\
\hline Empadão goiano & $95,6 \%$ & 22 \\
\hline Galinhada & $89,9 \%$ & 21 \\
\hline Pamonha de sal & $91,3 \%$ & 17 \\
\hline Peixe na Telha & $73,9 \%$ & 18 \\
\hline Preparação Doce & & 21 \\
\hline Biscoito do céu & $78,2 \%$ & \\
\hline Pastelinho & $91,3 \%$ & \\
\hline
\end{tabular}

O Arroz de pequi e o Empadão Goiano foram as preparações mais encontradas entre os pratos salgados sendo localizados em 95,6\% das fontes, totalizando vinte e duas referências. Seguido da pamonha de sal com 91,3\%, da galinhada com 89,9\%, do arroz com guariroba com $82,6 \%$ e do peixe na telha com $73,9 \%$.

Dentre as preparações doces a que mais se destaca é o pastelinho que se encontra em vinte e uma fontes totalizando 91, 3\%. Seguido do biscoito do céu em 78,2\% das referências.

Assim, pelo fato das preparações estarem em pelo menos $70 \%$ das fontes de receitas, considerou-se que são, portanto, reconhecidas como típicas dessa região.

Esses se mostram claramente nas influências de colonizadores nos pratos típicos de Goiás, como a presença do milho, embutidos, galinha, etc.

Por ser um grande produtor de arroz e por possuir elementos propícios para o crescimento de pequizeiros, o Estado é um dos maiores apreciadores da fruta, que combinada ao arroz se torna uma de suas receitas mais famosas (ARAÚJO et. al, 2005). Tendo também se tornado um símbolo cultural com presença marcante em festas culturais. Assim como a 
guariroba, que além de enfeitar as ruas das cidades da região, é um prato muito apreciado pela população. Por isso são tão citados nos receituários nacionais (CAVALCANTI, 2007).

A pamonha herdada de Minas também se transformou num símbolo para festas e comemorações culturais, onde recebeu ingredientes novos e temperos variados como o pequi. Variação esta que aparece em muitas pamonharias, típicas das cidades goianas (FERNANDES, 2007).

Por ser uma região extremamente irrigada os peixes são de uma grande variedade e são bem aceitos pela população. Como na receita do peixe na telha que é considerado um prato típico (CAVALCANTI, 2007).

Os doces são muito importantes, pois retratam especialmente uma fase onde as mulheres da região vendiam muito nas ruas para sustentar suas famílias. Por não ser fácil as comunicações entre as cidades de outras regiões muito se utilizou da terra para realizar preparações. As frutas, encontradas facilmente no cerrado, estão muito inseridas nas receitas antigas das doceiras da região (ARTIAGA, 1970).

Todos esses pratos, juntamente com todos os outros frutos e preparações utilizadas na região, fazem a cozinha típica do Centro-Oeste, e mesmo fazendo parte desta cultura os frutos do cerrado têm pouco destaque na literatura, os frutos são consumidos, principalmente na forma de sucos e doces caseiros, pela população local de algumas áreas específicas das regiões Norte e Central. O Ministério da Saúde do Brasil tem estimulado a implementação de programas de educação alimentar para incentivar o consumo de alimentos ricos em vitamina A e em outros nutrientes (CONSEA, 2008). Muitos destes alimentos, como as frutas nativas, apresentam custo acessível, mesmo para as populações mais carentes. $\mathrm{O}$ uso sustentado destas fruteiras nativas pode ser uma excelente opção para melhorar a saúde da população brasileira e para agregar valor aos recursos naturais disponíveis no cerrado, melhorando a renda das pequenas comunidades rurais e favorecendo a preservação das espécies nativas (ALMEIDA, 1998).

Com estimulo governamental e por parte dos profissionais de gastronomia é possível conseguir maior destaque para os frutos menos conhecidos, sendo necessário também aperfeiçoar acesso a esses produtos. 


\section{CONCLUSÃO}

É de grande importância realizar-se uma pesquisa em relação ao passado cultural e gastronômico do Brasil, já que por sermos um país novo, possuímos uma cultura que está em constante formação e que é uma mistura rica de passado e presente.

Descobrir de onde viemos pode nos ajudar a entender melhor para onde estamos indo e do que somos feitos. Já que sabemos que somos o que comemos, é preciso saber mais sobre o que comemos para descobrirmos quem somos.

As preparações típicas da região e suas matérias-primas são de grande importância para a região, pois moldam a história e o folclore do Centro-Oeste. Essa culinária típica que ainda vem se desenvolvendo é marcante, pois mostra e divulga os produtos encontrados nessa região, como os frutos do cerrado. Assim como o arroz com pequi, a guariroba e a pamonha de sal que são sempre relacionados à região pela importância histórica e popular.

A busca pelo desenvolvimento sustentável para o alcance da segurança alimentar da região prioriza a preservação desse bioma, além do seu desenvolvimento econômico. O que pode trazer maiores benefícios à população como um todo. Apesar de não serem muito utilizados, os frutos do cerrado têm sua importância na cultura da região, sendo necessária a divulgação dos mesmos para uma maior utilização e conhecimento.

Assim, é importante buscar um maior conhecimento sobre os produtos do cerrado mostrando para todo o país e para o mundo o enorme potencial gastronômico desta região. 


\section{REFERÊNCIAS BIBLIOGRÁFICAS}

ABRÃO, S. Santas Receitas. São Paulo: Editora gente, 2007.

ALMEIDA, S.P. de. Cerrado: aproveitamento alimentar. Planaltima: EMBRAPACPAC, 1998.

ANDRADE, A. C. S. de, SOUZA, A. F. de, R., FLAVIO NUNES et al. Germinação de sementes de jenipapo: temperatura, substrato e morfologia do desenvolvimento pósseminal. Pesq. agropec. bras., , vol.35, no.3, p.609-615. Mar. 2000.

ARAÚJO, W.M.C; BOTELHO, R.B.A.; GINANI, V.C.; ARAÚJO, H.M.C.; ZANDONADI, R.P. Da alimentação à gastronomia. Brasília: Ed. UnB; 2005.

ARTIAGA, Z. História de Goiás. 2ª ed. Goiânia: [s.n.], 1970.

AUTRAN, C. Sabores do Brasil - Receitas de Embaixada. São Paulo: Editora Record, 2006.

BARBOSA, L. Feijão com arroz e arroz com feijão: o Brasil no prato dos brasileiros. Horiz. antropol. [online]., vol. 13, no. 28. 2007

BATALHA M.A. \& MANTOVANI, W.. Floristic composition of the cerrado in the Pé-de-Gigante Reserve (Santa Rita do Passa Quatro, Southeastern Brazil). Acta Bot. Bras. 15(3):289-304. 2001

BARREIRO, D. P. e MACHADO, S. R.. Coléteres dendróides em Alibertia sessilis (Vell.) K. Schum., uma espécie não-nodulada de Rubiaceae. Rev. bras. Bot., , vol.30, no.3, p.387-399 jul./set. 2007.

BARRETO, S. M., PINHEIRO, ANELISE R. de O., SICHIERI, R. et al. Análise da estratégia global para alimentação, atividade física e saúde, da Organização Mundial da Saúde. Epidemiol. Serv. Saúde, vol.14, no.1, p.41-8. , mar. 2005 BINS, P. Brasil Receitas de Criar e Cozinhar. Rio de Janeiro: Editora Bertrand Brasil, 1998.

BERNACCI, L. C., MARTINS, F. R.e SANTOS, F. A. M. dos. Estrutura de estádios ontogenéticos em população nativa da palmeira Syagrus romanzoffiana (Cham.) Glassman (Arecaceae). Acta Bot. Bras., , vol.22, no.1, p.119-130 jan./mar. 2008.

BOLZANI, V. da S.;SILVA, V. C. da, SILVA, G. H., et al. Isolation of lignans glycosides from Alibertia sessilis (Vell.) K. Schum. (Rubiaceae) by preparative highperformance liquid chromatography. Eclet. Quím., , vol.31, no.4, p.55-582006. 
BOTEZELli, L.; DAVIDE, A. C.; MALAVASI, M. M. Características dos frutos e sementes de quatro procedências de Dipteryx alata Vogel (baru). Cerne, v.6, n.1, p.09-18, 2000 .

CASCUDO, L. C. História da alimentação no Brasil. $3^{a}$ ed. São Paulo: Global, 2004 .

CAVALCANTI, P. A pátria nas panelas: história e receitas da cozinha brasileira. São Paulo: Editora Senac São Paulo, 2007.

CHAVES, L. J., SILVA, R. S. M. e NAVES, R. V. Caracterização de frutos e árvores de cagaita (Eugenia dysenterica DC.) No sudeste do estado de Goiás, Brasil. Rev. Bras. Frutic., , vol.23, no.2, p.330-334. ago. 2001.

CHAVES, M. H., BARBOSA, A. S., MOITA NETO, J. M. et al. Caracterização química do óleo da amêndoa de Sterculia striata St. Hil. et Naud. Quím. Nova, , vol.27, no.3, p.404-408. maio/jun. 2004.COELHO, M. de A. Geografia do Brasil. 4ª Ed. São Paulo: Editora Moderna, 1998.

COLSON, H. Receitas de Anita - Doces e Salgados. São Paulo: Editora Verbo, 2005.

COMAS, A. 100 Receitas de Arroz. Porto Alegre: Editora L\&PM, 2003.

CONSEA Segurança Alimentar, Conselho Nacional de Segurança Alimentar, 2008. Disponível em HTTPS://www.planalto.gov.br/Consea. Acessado em 09 julho 2008.

COSTA, L.C.A.; MELLO, L.I.A. História do Brasil. 11 ${ }^{\text {a }}$ Ed. São Paulo: Scipione, 1991.

CORALINA, C. Villa Boa de Goyaz. Goiás - GO: Editora Global, 2001.

CUNHA, M. do C. L.; FERREIRA, R. A. Aspectos morfológicos da semente e do desenvolvimento da planta jovem de Amburana cearensis (Arr. Cam.) A.C. Smith - Cumaru Leguminosae Papilionoideae. Rev. bras. sementes, Pelotas, v.25, n.2, 2003.

ELIAS, S. R.M., ASSIS, R. M., STACCIARINI-SERAPHIN, E. et al. Anatomia foliar em plantas jovens de Solanum lycocarpum A.St.-Hil. (Solanaceae). Rev. bras. Bot., , vol.26, no.2, p.169-174. jun. 2003.

FAIFAX. O Grande Livro de Receitas. São Paulo: Editora Manole, 1998.

FALEIRO, F.G.; JUNQUEIRA, N.T.V.; BRAGA, M.F. (Ed.). Maracujá: germoplasma e melhoramento genético. Planaltina Distrito Federal: Embrapa Cerrados, 2005. p.559-586.

FARROW, J. Peixes - 80 das Melhores Receitas. São Paulo: Editora Manole, 2007. 
FERNANDES, C. Viagem gastronomica através do Brasil. $8^{a}$ ed. São Paulo: Editora Senac São Paulo, 2007.

FERREIRA, Y. N. Metrópole sustentável?: não é uma questão urbana. São Paulo Perspec., , vol.14, no.4, p.139-144 Out 2000.

GAIA, José Maria D., MOTA, Milton Guilherme da C., CONCEICAO, Carmen Célia C. da et al. Similaridade genética de populações naturais de pimenta-de-macaco por análise RAPD. Hortic. Bras., , vol.22, no.4, p.686-689 Oct./Dec. 2004.

GODOY, S. Histórias e Receitas - Deliciosas lembranças no fazer pedagógico. Porto alegre: Editora Palmarinca, 2007.

GONÇALVES, C. W. P. Geografia política e desenvolvimento sustentável. Terra Livre, v.11/12, p. 9-76. 1996

JACOMASSI, E., MOSCHETA, I. S. e MACHADO, S. R.. Morfoanatomia e histoquímica de Brosimum gaudichaudii Trécul (Moraceae). Acta Bot. Bras., , vol.21, no.3, p.575-597 July/Sept. 2007.

KLIGERMAN, D. C., VIlELA, H., CARDOSO, T. A. de O. et al. Sistemas de indicadores de saúde e ambiente em instituições de saúde. Ciênc. saúde coletiva,. vol.12, no.1, p.199-211, jan./mar. 2007.

KOSHIBA, L.; PEREIRA D. M. F. História do Brasil - No contexto da história. $8^{\text {a }}$ Edição. São Paulo: Editora Atual, 2003.

LACERDA, R. Folclore brasileiro - Goiás. Goiânia: Funarte, 1997.

LANCELLOTTI, S. 100 Receitas de Pescados. Porto Alegre: Editora L\&PM, 2008.

LANCELlOTTI, S. 500 Anos de Gastronomia em Terra Brasilis. Porto Alegre: Editora L\&PM, 2000.

LANCEllotTI, S. O Livro da Cozinha Clássica - A história das receitas mais famosas da história. Porto Alegre: Editora L\&PM, 2003

LEITE, M. Brasil - Ritmos e receitas. São Paulo: Editora GAIA, 2006.

LIMA, A.; SILVA, A.M. de O. e; TRINDADE, R.A.; TORRES, R. P.; MANCINIFILHO, J. Composição química e compostos bioativos presentes na polpa e na amêndoa do pequi (Caryocar brasiliense, Camb.). Rev. Bras. Frutic., , vol.29, no.3, 2007

LIMA, A. M., VIDAURRE, G. B., LIMA, R. de M. et al. Utilização de fibras (epicarpo) de babaçu como matéria-prima alternativa na produção de chapas de madeira aglomerada. Rev. Árvore, jul./ag 2006) 
MAEDA, R. N., PANTOJA, L., YUYAMA, L. K.O. et al. Determinação da formulação e caracterização do néctar de camu-camu (Myrciaria dubia McVaugh). Ciênc. Tecnol. Aliment., vol.26, no.1, p.70-74. jan/mar. 2006.

MARIM, A. M. F. Potencial Nutritivo de Frutos do Cerrado: composição em minerais e componentes não convencionais. 2006.108f. Dissertação (Mestrado em Nutrição Humana) - Universidade de Brasília, Brasília, 2006.

MARIMON JUNIOR, B. H. , HARIDASAN, M. Comparação da vegetação arbórea e características edáficas de um cerradão e um cerrado sensu stricto em áreas adjacentes sobre solo distrófico no leste de Mato Grosso, Brasil. Acta Bot. Bras., , vol.19, no.4, p.913-926 Oct./Dec. 2005.

MARTINS-CORDER, M. P. e SALDANHA, C.W.. Germinação de sementes e crescimento de plântulas de diferentes progênies de Euterpe edulis Mart.. Rev. Árvore,, vol.30, no.5, p.693-699. set./out. 2006.

MATUDA, T. G. and MARIA NETTO, F.. Caracterização química parcial da semente de jatobá-do-cerrado (Hymenaea stigonocarpa Mart.). Ciênc. Tecnol. Aliment., , vol.25, no.2, p.353-357 Apr./June 2005.

MORO, A. M. 400 Receitas Práticas De Dona Mimi $3^{\text {a }}$ Ed. Porto alegre: Editora Age, 1998.

MEIRA-NETO, J. A. A , MARTINS, F. R.. Composição florística de uma floresta estacional semidecidual montana no município de Viçosa-MG. Rev. Árvore, vol.26, no.4, p.437-446 July/Aug. 2002.

MELCHIOR, Saulo José, CUSTODIO, Ceci Castilho, MARQUES, Tadeu Alcides et al. Colheita e armazenamento de sementes de gabiroba (Campomanesia adamantium Camb. Myrtaceae) e implicações na germinação. Rev. bras. sementes, , vol.28, no.3, p.141-150 dez. 2006.

MELETTI, L.M. M., SOARES-SCOTT, M.D. e BERNACCI, L. C. Caracterização fenotípica de três seleções de maracujazeiro-roxo (Passiflora edulis Sims). Rev. Bras. Frutic., vol.27, no.2, p.268-272 ago. 2005.

MELO, J. T.; GUIMARÃES, D.P. Desenvolvimento da Guariroba em Sistemas Agroflorestais no Cerrado. Planaltina-DF: Embrapa Cerrados, 2002.

MIELKE, M.S., HOFFMANN, A., ENDRES, L. et al. Comparação de métodos de laboratório e de campo para a estimativa da área foliar em fruteiras silvestres. Sci. agric. Piracicaba, Braz., , vol.52, no.1, p.82-88 jan./abr. 1995. 
MINTZ, S. W. Comida - Uma breve revisão. Rev. Bras. Ci. Soc. vol. 16 n. 47. Out. 2001.

MONTEIRO, C. A.. A dimensão da pobreza, da desnutrição e da fome no Brasil. Estud. av., , vol.17, no.48, p.7-20. May/Aug. 2003.

NACHTIGAlL, A. M. et al. Geléias light de amora-preta. Boletim do Centro de Pesquisa e Processamento de Alimentos, Curitiba, n. 2, p. 337-354, jul./dez. 2004.

NASCIMENTO, G.. Estudo histológico do efeito agudo de extrato de annomna coricea (araticum) sobre o cerebelo de camoundongos swiss Revista Eletrônica de Farmácia, Goiania, p.32-41,2007

OLIVEIRA, A. L. de, ALMEIDA, E. de, SILVA, F. B. R.da et al. Elemental contents in exotic Brazilian tropical fruits evaluated by energy dispersive X-ray fluorescence. Sci. agric. Piracicaba, Braz.,. 2006, vol.63, no.1, p.82-84 jan./fev.

OliveIRA COSTA, D. L. de Cozinha da Roça - Delícias do Brasil Interiorano. Porto Alegre: Editora Nova Alexandria, 1998.

ORTÊNCIO, B. Cozinha goiana. Goiânia: Editora Kelps, 2000.

PEREIRA, Luiz Alfredo Rodrigues, CALBO, Maria Elisa Ribeiro e FERREIRA, Claiton Juvenir. Anatomy of pneumatophore of Mauritia vinifera mart. Braz. arch. biol. technol, vol.43, no.3, p.327-333, 2000

POLONIAL, J. Terra do Anhagüera- História de Goiás. $2^{a}$ ed. São Paulo: Arcádia, 2005

RIBEIRO, G. Geografia e Atlas do Brasil. São Paulo: Editora do Brasil, 1966.

REIS, R. 1000 Receitas da Culinária Brasileira. São Paulo: Editora Girassol, 2005.

REZENDE, C. M. e FRAGA, S. R. G. Chemical and aroma determination of the pulp and seeds of murici (Byrsonima crassifolia L.). J. Braz. Chem. Soc., , vol.14, no.3, p.425-428 maio/jun. 2003.

RODRIGUES, A. G. Buscando raízes. Horiz. antropol. , Porto Alegre, v. 7, n. 16,2001

RODRIGUES, V.E.G, CARVALHO DA. Levantamento etnobotânico de plantas medicinais no domínio do cerrado na região do alto rio grande - Minas Gerais. Ciênc Agrotec 25: 102-123, 2001.

ROESLER, R., MALTA, L. G., CARRASCO, L. C. et al. Atividade antioxidante de frutas do cerrado. Ciênc. Tecnol. Aliment, vol.27, no.1, p.53-60., Jan./Mar. 2007. 
ROESLER, T. Sabor Rural - 50 Receitas com tempero de Brasil. Porto Alegre: Editora RBS Publicações, 2004.

ROSA, H. In: CORALINA, C. Poemas dos Becos de Goiás e estórias mais. 12a edição Goiás - GO:Editora Global, 1986.

ROSSETTI, A. G.; SILVEIRA, E. R. Metodologia para determinação de ácido anacárdico em pedúnculos de caju. Revista Brasileira de Plantas Medicinais, v.5, n. 2, p. 77-81, 2003.

SANTOS, M. H.; NAGEM, T. J.; OLIVEIRA, T. T.; OLIVEIRA, J. R.; LIMA, R. D.; QUEIROZ, M. E. L. R.; MIRANDA, L. C. G. Efeito de constituintes químicos extraídos do fruto de Rheedia gardneria (bacuparí) sobre bactérias fitopatogênicas. Revista Brasileira de Ciências Farmacêuticas, São Paulo, v.35, n.2, p.297-30, 1999.

SANTOS, W. L. dos et al. Effect of the aqueous extracts of the seeds of Talisia esculenta and Sapindus saponaria on fall armyworm. Braz. arch. biol. technol., , vol.51, no.2, p.373-383 Apr 2008.

SEPLAN. Goiás em dados, aspectos físicos, vegetação. Goiás, 2003; Disponível em HTTP:// www.seplan.go.gov.br. Acesso em: 09 julho 2008.

SILVA, D. B. da; SILVA, J. A. da; JUNQUEIRA, N. T. V.; ANDRADE, L. R. M. de. Frutas do Cerrado. Brasília: Embrapa Informação Tecnológica, 2001.

SILVA, S. M. da. 100 Melhores Receitas de Restaurantes. São Paulo: Editora Edicon, 2006.

SILVA JUNIOR, J. F.. A cultura da mangaba. Rev. Bras. Frutic., , vol.26, no.1, p.0-0 abr. 2004.

SILVA JÚNIOR, M. C. da, 100 Árvores do Cerrado: guia de campo. Brasília, Ed. Rede de Sementes do Cerrado, 2005.

SILVEIRA, C.S. et al. Atividade antimicrobiana dos frutos de Syagrus oleracea e Mauritia vinifera. Rev. bras. farmacogn., , vol. 15, no. 2, Jun 2005.

SPIRONELlO, A., QUAGGIO, J.A., TEIXEIRA, L. A. J. et al. Pineapple yield and fruit quality effected by NPK fertilization in a tropical soil. Rev. Bras. Frutic., , vol.26, no.1, p.155-159. abr. 2004.

TREVISAN, B; BARBOSA, T. M; MATTOS, N.; RAMOS, R. H.P. Sabores da cozinha brasileira. São Paulo: Melhoramentos, 2004.

VESENTINI, J.W. Sociedade e Espaço. São Paulo: Editora Ática, 1992. 
VILAR, JB., FERREIRA, FL., FERRI, PH. et al. Assessment of the mutagenic, antimutagenic and cytotoxic activities of ethanolic extract of araticum (Annona crassiflora Mart. 1841) by micronucleus test in mice. Braz. J. Biol., , vol.68, no.1, p.141-147. fev. 2008. 


\section{ANEXOS}

\section{ANEXO A - RECEITA DE ARROZ DE PEQUI}

Ingredientes

5 pequis bem amarelos, lavados

4 colheres (sopa) de óleo ou banha de porco

2 dentes de alho amassados

1 cebola grande, picada

2 xícaras de arroz lavado e escorrido

Sal e pimenta-de-cheiro ou pimenta malagueta fresca, picada, a gosto

1 colher (sopa) de cheiro-verde (salsa e cebolinha verde) picado

Modo de preparo

Retire a casaca dos pequis, ponha-os numa panela, junte o óleo ou banha, o alho e a cebola. Leve ao fogo brando e refogue, mexendo sempre, até a cebola e o alho ficarem dourados.

Acrescente o arroz e frite um pouco. Junte a água, tempere com sal a gosto e cozinhe até o arroz ficar macio e a água secar. Acrescente pimenta a gosto e misture delicadamente.

Tire do fogo, polvilhe com cheiro-verde e mais um pouco de pimenta, e leve à mesa.

Fonte: FERNANDES, 2007 


\section{ANEXO B: RECEITA DE ARROZ COM GUARIROBA}

Ingredientes

4 colheres (sopa) de manteiga

2 dentes de alho picados

2 cebolas médias picadas

$400 \mathrm{~g}$ de guariroba ou palmito cortado em pedaços pequenos

2 xícaras de arroz

4 xícaras de água quente

1 pimenta-de-cheiro picada

Salsinha e cebolinha picada para polvilhar

Pimenta-do-reino a gosto

1 cebola pequena picada

1 colher (chá) de vinagre

Sal a gosto

Modo de preparo

Numa panela, derreta a manteiga, acrescente o alho e as cebolas médias e deixe refogar em fogo baixo, mexendo de vez em quando. Adicione a guariroba e refogue por uns 5 minutos, mexendo sempre com uma colher de pau.

Acrescente o arroz, frite um pouco, junte água e tempere. Tampe a panela e deixe cozinhar. Antes de apagar o fogo, adicione a pimenta-de-cheiro, e, na hora de servir, acrescente e misture a cebolinha, a salsinha, a pimenta-do-reino, a cebola pequena e o vinagre.

Fonte: CAVALCANTI, 2007. 


\section{ANEXO C: RECEITA DE EMPADÃO GOIANO}

Ingredientes

Massa

$1 \mathrm{~kg}$ de farinha de trigo

$500 \mathrm{~g}$ de margarina (ou banha de porco)

1 colher (sopa) de fermento químico em pó

1 xícara de água, em temperatura ambiente

1 pitada de sal

3 gemas ligeiramente batidas, para pincelar

\section{Recheio}

$3 \mathrm{~kg}$ de peito de frango, temperado, frio e desfiado

$1 / 2 \mathrm{~kg}$ de lombo ou pernil de porco, temperado e frito, cortado em cubos

4 ovos cozidos duros, cortados em cubinho

$300 \mathrm{~g}$ de queijo-de-minas meia cura cortado em cubinhos

20 azeitonas

1 guariroba, cortada bem fininha e refogada (ou 1 pote de palmito em conserva)

Salsa e cebolinha verde

\section{Molho}

2 latas de molho de tomate

1 lata de extrato de tomate

Salsa e cebolinha

Pimenta-bode

Pimenta-do-reino

4 colheres (sopa) de farinha de trigo

Modo de preparo

Ponha todos os ingredientes da massa numa tigela, misture e junte, aos poucos, 1 xícara de água morna salgada com $1 / 2$ colher (sopa) de sal, enquanto vai amassando com as 
mãos até obter uma massa maleável. Forme uma bola, cubra com um pano e deixe descansar 1 hora.

Prepare o molho na frigideira onde foram fritos o frango e o lombo de porco, acrescente o molho de tomate, o extrato, salsa cebolinha e as pimentas.

Junte $2 \frac{1}{2}$ de água e junte a farinha dissolvida num pouco d água. Mexa até ficar bem uniforme. Deixa esfriar completamente antes de rechear.

Aqueça o forno em temperatura média $\left(180^{\circ} \mathrm{C}\right)$.

Prepare as fôrmas de empada de $10 \mathrm{~cm}$ de diâmetro: abra a massa com o rolo e forre. Distribua o recheio assim: em cada fôrma ponha, na ordem, uma camada de frango, a seguir o lombo, os ovos, o queijo, uma azeitona e o palmito. Regue com o molho, cubra com a massa restante, faça o torcidinho tradicional ao redor da empada, pincele com uma gema e leve ao forno pré-aquecido par dourar.

Fontes: FERNANDES, 2007. 


\section{ANEXO D: RECEITA DE GALINHADA}

Ingredientes

1 galinha de $1,5 \mathrm{~kg}$ a $2 \mathrm{~kg}$

$1 / 2$ colher (sopa) de sal

4 pimentas-bode picadas

Colheres (sopa) de suco de limão

1 pimentão vermelho pequeno picado

1 dente de alho espremido

2 cebolas pequenas picadas

4 tomates

1 xícara de água

2 colheres (sopa) de óleo

1 colher (sopa) de manteiga

2 fatias de bacon picado

$1 / 2$ colher (chá) de açafrão da terra (cúrcuma)

Salsinha e cebolinha picadas a gosto

\section{Modo de preparo}

Corte a galinha em pedaços e tempere com o sal, a pimenta-bode, o suco de limão, o pimentão, o alho e as cebolas. Deixe descansar na geladeira por 2 horas. Numa panela, coloque os tomates, a água, e uma pitada de sal, tampe e deixe cozinhar por 10 minutos, depois que começar a ferver. Deixe esfriar um pouco e bata no liquidificador.

Em outra panela, coloque o óleo, a manteiga, o bacon e o açafrão. Aqueça e frite os pedaços de galinha aos poucos, virando de vez em quando, até que estejam dourados. Coloque os pedaços de galinha no molho batido, leve ao fogo novamente e cozinhe até a carne ficar macia. Acrescente a salsinha e a cebolinha picadas e sirva bem quente.

Fonte: CAVALCANTI, 2007. 


\section{ANEXO E: RECEITA DE PAMONHA DE SAL}

Ingredientes

30 espigas (cerca de $6 \mathrm{~kg}$ ) de milho verde

4 colheres (sopa) de banha de porco ou manteiga bem quente

Sal a gosto

1 colher (sopa) de tempero desidratado

1 pitada de açúcar

$1 \mathrm{~kg}$ de lingüiça calabresa cortada em rodelas

Modo de preparo

Com uma faca afiada, corte a base das espigas de milho, tire as palhas, reserve-as para embrulhar as pamonhas e elimine os cabelos. Rale as espigas e, com a faca, raspe o sabugo para extrair o milho restante. Passe para uma peneira grossa, junte a banha de porco ou manteiga, tempere com sal a gosto, tempero desidratado e o açúcar. Acrescente as rodelas de lingüiça e misture bem.

Faça pacotinhos com a palha de milho, encha com a mistura preparada e amarre a extremidade com uma tira de palha molhada ou barbante.

Encha uma panela grande com bastante água, leve ao fogo alto e deixe ferver.

Junte as pamonhas e cozinhe até a palha ficar amarelada.

Tire a pamonha do fogo e sirva quente acompanhada de café e manteiga.

Fonte: FERNANDES, 2007. 


\section{ANEXO F: RECEITA DE PEIXE NA TELHA}

Ingredientes

$500 \mathrm{~g}$ pintado em postas

2 Alho

1 Limão

Pimenta-bode a gosto

Sal a gosto

$100 \mathrm{~g}$ farinha de trigo

1/2 litro de óleo

Caldo

4 colheres de sopa de óleo

1 cebola

2 colheres de sopa de páprica

2 pimentões cortados em cubos

cheiro verde picado a gosto

1 vidro de leite de coco

100 gr de azeitona

2 tomates s/pele, cortados em cubos

5 colheres de sopa de farinha de mandioca

Modo de Preparo

Tempere o Pintado, com sal, pimenta e limão, passe-o pela farinha e frite. Reserve.

Prepare o caldo, refogue no óleo a cebola e os temperos, acrescente o leite de coco e por último a farinha. Despeje o caldo na telha, acrescente as postas sobre o caldo e leve ao forno pré-aquecido $250^{\circ} \mathrm{C}$ para gratinar. Sirva com Arroz.

Fonte: ORTÊNCIO, 2000. 


\section{ANEXO G: RECEITA DE BISCOITO DO CÉU}

Ingredientes

3 cocos ralados e água de 1 coco

$500 \mathrm{~g}$ de açúcar refinado

$1,5 \mathrm{~kg}$ de polvilho

4 ovos

$1 \frac{1}{4}$ de xícara de manteiga

1 pitada se sal

Canela em pó a gosto

Modo de preparo

Para fazer o leite de côco, leve o côco ralado e a água do mesmo ao fogo e esquente bem. Depois, coloque num guardanapo e esprema para sair o leite grosso. Numa panela, misture o açúcar e o polvilho. Depois adicione o leite de coco e amasse bem.

Junto 2 ovos (se for preciso, coloque também os outros dois), a manteiga e só no final acrescente o sal e a canela. Amasse aos poucos, porque a massa é dura.

Faça bolinha e asse em assadeira levemente untada, em forno moderado $\left(180^{\circ} \mathrm{C}\right)$, préaquecido, por 20 minutos, ou até dourar a parte inferior.

Fonte: CAVALCANTI, 2007. 


\section{ANEXO H: RECEITA DE PASTELINHA}

Ingredientes

$1 \mathrm{~kg}$ de farinha de trigo

$500 \mathrm{~g}+2$ colheres (sopa) de margarina

1 colher (sopa) de fermento químico em pó

1 xícara de água na temperatura ambiente

1 pitada de sal

Canela em pó para polvilhar

Modo de preparo

Ponha todos os ingredientes numa tigela média, junte 1 xícara de água, misture e amasse com as mãos.

Aqueça o forno a temperatura média $\left(180^{\circ} \mathrm{C}\right)$.

Forre as forminhas pequenas para empadinhas com a massa. Com uma colherzinha forme ondas ao redor da forminha. Leve ao forno pré-aquecido até dourar a massa.

Tire do forno, recheie com doce de leite e leve de volta ao forno apenas para derreter o doce. Sirva polvilhados com canela.

Fonte: FERNANDES, 2007. 
"Poema com Açúcar"

Para Aninha

Doces e poemas

Poemas que são doces

Doces de poemas

De Cora doceira

De Cora da ponte

De Cora da fonte...

da vida

Canto o poema

Poema de encanto

Poema que aflora

Da doce Cora

Alma com açúcar

Mãos com poesia

Céu Vermelho

Rio Vermelho

Vermelhos frutos

caju e amora

São doces os divinos doces

feitos por Cora

Canto a juventude

De Cora doceira

De Cora da ponte

De Cora da fonte

(...) “

Rosa, Heitor. In: Coralina, Cora. Poemas dos becos de Goiás e estórias mais . 16. ed. p. 33 